\title{
The Addition of Lactobacillus spp., Enrofloxacin or Doxycycline Negatively Affects the Viability of Mycoplasma bovis in Diluted Bovine Semen
}

\author{
Ana García-Galán ${ }^{1}{ }^{1}$, Ángel Gómez-Martín ${ }^{1,2, *}$, Esther Bataller ${ }^{2}$, Jesús Gomis ${ }^{2}$, \\ Antonio Sánchez ${ }^{1}$, Joaquín Gadea ${ }^{3,4} \mathbb{D}$, Luis Alberto Vieira ${ }^{3,4} \mathbb{D}$, Empar García-Roselló ${ }^{2} \mathbb{D}$ and \\ Christian De la Fe ${ }^{1}$ \\ 1 Ruminant Health Research Group, Department of Animal Health, Faculty of Veterinary Sciences, \\ Regional Campus of International Excellence "Campus Mare Nostrum", University of Murcia, 30100 Murcia, \\ Spain; ana.garcia25@um.es (A.G.-G.); asanlope@um.es (A.S.); cdelafe@um.es (C.D.1.F.) \\ 2 Microbiological Agents Associated with Animal Reproduction (ProVaginBio) Research Group, \\ Department of Animal Health and Public Health, Faculty of Veterinary Sciences, University CEU Cardenal \\ Herrera of Valencia, CEU Universities, 46113 Valencia, Spain; esther.bataller@uchceu.es (E.B.); \\ jesus.gomis1@uchceu.es (J.G.); empar@uchceu.es (E.G.-R.) \\ 3 Physiology of Reproduction Research Group, Department of Physiology, Faculty of Veterinary Sciences, \\ Regional Campus of International Excellence "Campus Mare Nostrum", University of Murcia, 30100 Murcia, \\ Spain; jgadea@um.es (J.G.); luisalberto.vieira@um.es (L.A.V.) \\ 4 Institute for Biomedical Research of Murcia IMIB-Arrixaca, 30100 Murcia, Spain \\ * Correspondence: angel.gomezmartin@uchceu.es
}

Received: 7 April 2020; Accepted: 12 May 2020; Published: 13 May 2020

check for updates

Simple Summary: Mycoplasma bovis is an important infectious agent in cattle. The pathogen may cause a wide range of clinical signs, including mastitis, arthritis, pneumonia and reproductive disorders. Artificial insemination with contaminated semen may be a source of infection in infection-free areas or herds. Hence, the antimicrobials used in the preparation of seminal doses should be re-evaluated, or alternative measures to antimicrobials should be tested. This in vitro study aims to evaluate novel strategies to reduce the risk of the transmission of the pathogen through contaminated semen during artificial insemination. Hence, we assess the effect of the addition of (1) the antimicrobial enrofloxacin, (2) the antimicrobial doxycycline, or (3) a probiotic of human origin that contains acid lactic bacteria of the genus Lactobacillus, on the viability of Mycoplasma bovis in diluted bull semen in a Tris-citrate-fructose medium. The data show that the pathogen is negatively affected by the addition of $0.125 \mu \mathrm{g} / \mathrm{mL}$ of enrofloxacin, $0.0625 \mu \mathrm{g} / \mathrm{mL}$ of doxycycline, or the probiotic at a concentration of $3.24 \times 10^{6}$ or $3.24 \times 10^{8}$ colony-forming units $/ \mathrm{mL}$ in diluted semen. Our results are promising in the field, as they may support new strategies to reduce the risk of the transmission of Mycoplasma bovis through artificial insemination.

Abstract: Mycoplasma bovis is an important etiologic agent of bovine mycoplasmosis in cattle. Different transmission routes have been described, including those related to reproduction. The presence of mycoplasma in semen has led to its appearance in infection-free areas through artificial insemination (AI). Semen was recently reported to be the initial source of two M. bovis mastitis outbreaks in two closed dairy herds in Finland. This questions the effectiveness of the antimicrobials currently used in semen extenders to control the pathogens in contaminated semen. They should be re-evaluated, or alternative measures to antimicrobials should be tested to obtain M. bovis-free semen. This in vitro study aimed to assess different strategies to reduce the risk of transmission of $M$. bovis through AI technologies. The viability of M. bovis (PG45, NCTC 10131) in bull semen diluted (DS) in a Tris-citrate-fructose solution was tested, after the addition of enrofloxacin, doxycycline or a Lactobacillus spp.-based probiotic. The data show the susceptibility of the pathogen to the addition 
of $0.125 \mu \mathrm{g} / \mathrm{mL}$ of enrofloxacin or $0.0625 \mu \mathrm{g} / \mathrm{mL}$ of doxycycline and to the addition of the probiotic at a concentration of $3.24 \times 10^{6}$ colony forming units $(\mathrm{CFU}) / \mathrm{mL}$ or $3.24 \times 10^{8} \mathrm{CFU} / \mathrm{mL}$ in DS. The Tris-citrate-fructose medium negatively affected the viability of $M$. bovis, although this effect was lower than that observed after the addition of the probiotic and antimicrobials $(p<0.05)$. Our results may support new strategies for reducing the risk of $M$. bovis transmission through AI.

Keywords: In vitro; viability; Mycoplasma bovis; diluted bull semen; enrofloxacin; doxycycline; Lactobacillus spp.

\section{Introduction}

Mycoplasma bovis is an important infectious agent, which is distributed worldwide and is responsible for substantial economic losses in the cattle industry [1]. The pathogen may cause mastitis, pneumonia, arthritis, otitis media, keratoconjunctivitis, and reproductive disorders [2]. In bulls, M. bovis may cause orchitis, vesiculitis, and decreased sperm quality [3,4].

Different transmission routes have been described, including those related to reproduction. Even if bulls with clinical symptoms of $M$. bovis infection are not used as semen donors, the existence of asymptomatic carriers may lead to the spread of the bacterium inside infection-free areas through contaminated semen used for artificial insemination (AI). This may have recently occurred in Finland, where semen was reported to be the initial source of $M$. bovis mastitis outbreaks in two close dairy herds [5]. Mycoplasma bovis can be isolated from commercial frozen semen [6,7], and several experimental studies have shown that $M$. bovis can survive the in vitro fertilization processes, infect embryos, and interfere with fertilization by reducing the sperm penetration capacity $[8,9]$.

Currently, semen extenders, employed to prepare bovine seminal doses, are supplemented with several antimicrobials to prevent the growth of semen contaminating bacteria, mainly acquired during the collection process. Penicillin, gentamicin, streptomycin, tylosin, spectinomycin, and lincomycin are among the most common antimicrobials added to semen extenders [10-12]. With regard to mycoplasmas, the addition of the same combination of gentamicin, tylosin, lincomycin, and spectinomycin has been effective or ineffective in different studies $[13,14]$. On the other hand, antimicrobials, such as enrofloxacin or doxycycline, have been shown to be efficient in inhibiting the growth of M. bovis in several in vitro studies $[15,16]$. However, the efficacy of these antimicrobials in bovine semen has not been assessed yet. Other tetracyclines, such as chlortetracycline and oxytetracycline, may be spermicidal for bovine sperm [17], but this has not been demonstrated for doxycycline. Furthermore, it has been shown in human patients that oral treatment with doxycycline for 10 days has no negative effect on sperm quality, compared to pre-treatment values. In fact, there may be a small benefit for patients with subnormal counts and motility [18].

Lacking a cell wall, mycoplasmas are very sensitive to environmental changes and especially to $\mathrm{pH}$ variations, which could be of interest in relation to the control of mycoplasma genital infections [19]. Indeed, the sensitivity of Mycoplasma agalactiae and Mycoplasma mycoides subsp. capri to the $\mathrm{pH}$ decreases in goat ejaculates and diluted semen was recently reported [20]. On the other hand, previous studies have demonstrated that lactic acid bacteria (LAB) of the genus, Lactobacillus spp., can inhibit the growth of human pathogenic bacteria through competition for resources, stimulation of the host immune system, and the production of hydrogen peroxide and acetic and lactic acids, which decrease $\mathrm{pH}$ [21,22]. LAB have been isolated in bovine semen [23], although their effect on the viability of bovine mycoplasmas is unknown. We believe that the viability of $M$. bovis in diluted bull semen (DS) may be affected by the addition of $\mathrm{LAB}$ as competing agents and $\mathrm{pH}$ acidifiers.

Alternative control measures are needed to reduce the risk of the transmission of the pathogen through AI. Hence, the objective of this study is to assess the viability of M. bovis in experimentally 
contaminated DS, after the addition of (1) an antimicrobial (enrofloxacin or doxycycline), or (2) a Lactobacillus spp.-based probiotic at different concentrations.

\section{Materials and methods}

\subsection{Semen Samples}

All animal procedures were performed following the EU Directive 2010/63/EU for animal experimentation and had the authorization of the Ethics Committee on Animal Testing of the University of Murcia (Number: 307/2017).

Samples from nine Aberdeen Angus bulls, between two and four years of age, from a herd in Teruel (Spain), were collected for this study on three different days. Four samples were collected on day 1 , three samples on day 2 , and two samples on day 3 .

An ejaculate sample was obtained from each bull by electroejaculation [24]. In the first place, the animals were sedated with xylazine (3-4 mg/100 Kg Rompun $₫ 2 \%$ i.m.; Bayer S.A., Barcelona, Spain). Then, the preputial area was washed and disinfected, and rectal ampoule emptying was carried out. An electroejaculator, with an automatic function (Electrojac 6, Humecoß) and a $63.5 \mathrm{~mm}$ three-electrode probe, was used. The electroejaculation program consisted of a consecutive series of increasing voltage, with two-second pulses, followed by a two-second pause. The ejaculates were then collected using a tempered glass collector in a graduated tube and diluted $\left(1 / 1,37^{\circ} \mathrm{C}\right)$ in a Tris-citrate-fructose medium ( $250 \mathrm{mM}$ Tris, $88 \mathrm{mM}$ citric acid, $14 \mathrm{mM}$ fructose; $325-350 \mathrm{mOsm}$; $\mathrm{pH}$ 7.0) [25]. Then, the DS samples were transported in an airtight isothermal container to the laboratory in less than four hours.

The sperm motility of each DS sample was assessed using the computer-assisted sperm analysis system (ISAS, Proiser, Valencia, Spain) [26]. Samples with a motility below $50 \%$ or with contamination signs were discarded. Two samples on day 1, two samples on day 2 , and two samples on day 3 were finally selected for the study. Each sample was adjusted to a concentration of $25 \times 10^{6} \mathrm{cells} / \mathrm{mL}$, and a pool of DS was prepared with the selected samples.

\subsection{M. bovis Inoculum}

The reference strain of $M$. bovis (PG45, NT 10131) was cultured in a modified broth SP4 medium [27], without any antimicrobial addition, supplemented with heat-inactivated horse serum (HIHS) instead of bovine serum, and incubated for 48 hours at $37^{\circ} \mathrm{C}$ in a humidified atmosphere with $5 \% \mathrm{CO}_{2}$. The initial concentration of the inoculum $\left(1 \times 10^{9}\right.$ colony-forming units $\left.(\mathrm{CFU}) / \mathrm{mL}\right)$ was calculated as previously described [28].

\subsection{Lactobacillus spp. Inoculums}

A commercial lyophilisate of human origin, based on Lactobacillus crispatus, Lactobacillus gasseri, and Lactobacillus brevis (NS Femibiotic $®$, Huarte, Pamplona, Navarra, Spain), was reconstituted in a modified broth SP4 and incubated for 24 hours at $37^{\circ} \mathrm{C}$. Two inoculums of Lactobacillus spp. (L1 and L2) were prepared at different concentrations $\left(3.24 \times 10^{6}\right.$ and $3.24 \times 10^{8} \mathrm{CFU} / \mathrm{mL}$, respectively).

\subsection{Determination of Minimum Inibitory Concentration (MIC)}

The MIC of enrofloxacin (Fluka, Bio-Chemika, Missouri, USA) and doxycycline (Sigma-Aldrich, St. Louis, Missouri, USA) was calculated for the PG45 strain. A stock solution (1 mg/mL) of each antimicrobial was prepared by dissolving the powder in sterile distilled water, from which 12 serial double dilutions were made. To prepare enrofloxacin, $0.1 \mathrm{M} \mathrm{HCL}$ was added dropwise until dissolution occurred, and the correct final volume was obtained by adding sterile distilled water. A final range from 128 to $0.0625 \mu \mathrm{g} / \mathrm{mL}$ was tested. A stationary-phase culture of the PG45 strain was used for MIC assays. The mycoplasma culture was carried out in a PH medium [29], supplemented with sodium pyruvate $(0.5 \%)$ and phenol red $(0.005 \%)$, and the mycoplasma titers were determined using a previously described method [28]. MIC assays were carried out in 96-well microtiter plates using 
the microbroth dilution method [30]. Briefly, $25.6 \mu \mathrm{L}$ of each antimicrobial dilution and $25 \mu \mathrm{L}$ of the diluted $M$. bovis inoculum $\left(10^{3}-10^{5} \mathrm{CFU} / \mathrm{mL}\right)$ were added to $150 \mu \mathrm{L}$ of the culture medium. After $48 \mathrm{~h}$ of incubation at $37^{\circ} \mathrm{C}$, the plates were examined for color change. MIC was defined as the lowest concentration of the antimicrobial capable of completely inhibiting the growth of the PG45 strain. This value was recorded for both antimicrobials and was $0.125 \mu \mathrm{g} / \mathrm{mL}$ and $0.0625 \mu \mathrm{g} / \mathrm{mL}$ for enrofloxacin and doxycycline, respectively. MIC assays were performed in duplicate. To accept the results, the MIC values had to be within one dilution, and the higher MIC value was used.

\subsection{Experimental Design}

Eleven in vitro experimental conditions (Table 1) were prepared, with a final volume of $1.5 \mathrm{~mL}$, using DS and/or modified SP4 to investigate the M. bovis viability after exposing it to two antimicrobials, enrofloxacin or doxycycline, or different concentrations of Lactobacillus spp. Previously, the MIC of PG45 was determined for both antimicrobials.

Table 1. Experimental conditions evaluated.

\begin{tabular}{|c|c|c|c|}
\hline Condition & Description & M. bovis & LAB \\
\hline 1 & $\mathrm{DS}_{(1460 \mu \mathrm{L})}+$ M. bovis $(40 \mu \mathrm{L})$ & $\checkmark$ & $\checkmark^{*}$ \\
\hline 2 & $\mathrm{DS}_{(1460 \mu \mathrm{L})}+\mathrm{L} 1_{(40 \mu \mathrm{L})}$ & & $\checkmark$ \\
\hline 3 & $\mathrm{DS}(1000 \mu \mathrm{L})+\mathrm{L} 2(500 \mu \mathrm{L})$ & & $\checkmark$ \\
\hline 4 & $\mathrm{DS}_{(1420 \mu \mathrm{L})}+$ M. bovis $(40 \mu \mathrm{L})+\mathrm{L} 1_{(40 \mu \mathrm{L})}$ & $\checkmark$ & $\checkmark$ \\
\hline 5 & $\mathrm{DS}_{(960 \mu \mathrm{L})}+$ M. bovis $(40 \mu \mathrm{L})+\mathrm{L} 2(500 \mu \mathrm{L})$ & $\checkmark$ & $\checkmark$ \\
\hline 6 & $\mathrm{SP}_{(1420 \mu \mathrm{L})}+$ M. bovis $(40 \mu \mathrm{L})+\mathrm{L} 1_{(40 \mu \mathrm{L})}$ & $\checkmark$ & $\checkmark$ \\
\hline 7 & $\mathrm{SP} 4(960 \mu \mathrm{L})+M$. bovis $(40 \mu \mathrm{L})+\mathrm{L} 2(500 \mu \mathrm{L})$ & $\checkmark$ & $\checkmark$ \\
\hline 8 & $\mathrm{DS}_{(1436 \mu \mathrm{L})}+$ M. bovis $(40 \mu \mathrm{L})+$ Enro $_{(24 \mu \mathrm{L})}$ & $\checkmark$ & \\
\hline 9 & $\operatorname{DS}_{(1436 \mu \mathrm{L})}+$ M. bovis $(40 \mu \mathrm{L})+\operatorname{Doxy}_{(24 \mu \mathrm{L})}$ & $\checkmark$ & \\
\hline 10 & $\mathrm{SP}_{(1436 \mu \mathrm{L})}+$ M. bovis $(40 \mu \mathrm{L})+$ Enro $(24 \mu \mathrm{L})$ & $\checkmark$ & \\
\hline 11 & SP4 $(1436 \mu \mathrm{L})+M$ bovis $_{(40 \mu \mathrm{L})}+\operatorname{Doxy}(24 \mu \mathrm{L})$ & $\checkmark$ & \\
\hline
\end{tabular}

DS: Diluted semen. SP4: Specific medium for Mycoplasma spp. isolation (conditions without DS). L1: Lactobacillus spp. less concentrated $\left(3.24 \times 10^{6} \mathrm{CFU} / \mathrm{mL}\right)$. L2: Lactobacillus spp. more concentrated $\left(3.24 \times 10^{8} \mathrm{CFU} / \mathrm{mL}\right)$. LAB: Lactic acid bacteria. $\checkmark$ : Counts of $M$. bovis and lactic acid bacteria were made. *: Lactic acid bacteria were isolated in the pool of diluted semen. Enro: Enrofloxacin. Doxy: Doxycycline.

Each condition was prepared in a sterile eppendorf tube. DS was added to conditions 1, 2, 3, 4, 5, 8 , and 9 to obtain the final volume of $1.5 \mathrm{~mL}$. In conditions $6,7,10$, and 11, a similar procedure was performed using SP4.

Posteriorly, $40 \mu \mathrm{L}$ of the $M$. bovis inoculum $\left(1 \times 10^{9} \mathrm{CFU} / \mathrm{mL}\right)$ was added to the conditions, followed by the addition of $40 \mu \mathrm{L}$ of L1, $500 \mu \mathrm{L}$ of L2 $\left(3.24 \times 10^{6} \mathrm{CFU} / \mathrm{mL}\right.$ and $3.24 \times 10^{8} \mathrm{CFU} / \mathrm{mL}$, respectively: Table 1), or $24 \mu \mathrm{L}$ of enrofloxacin or doxycycline (obtaining a final concentration of $0.125 \mu \mathrm{g} / \mathrm{mL}$ and $0.0625 \mu \mathrm{g} / \mathrm{mL}$, respectively, with a final volume of $1.5 \mathrm{~mL}$ : Table 1). The eppendorf tubes were incubated in a thermoblock (VWR, Radnor) at $37^{\circ} \mathrm{C}$ for 15 hours (15). After 15 minutes of incubation, 0 hour (h0) was established. The viability of $M$. bovis and LAB was determined at 0 and $15 \mathrm{~h}$ after exposure (h0 and h15, respectively).

Besides, $\mathrm{pH}$ measurements were made using an electronic $\mathrm{pH}$ meter at both times (Hamilton Minitrode, Bonaduz, Switzerland). The $\mathrm{pH}$ values of the pools of DS and SP4 were considered as the initial $\mathrm{pH}(\mathrm{h} 0)$ of the conditions prepared for DS and SP4, respectively. The $\mathrm{pH}$ was measured in every condition separately at h15.

The absence of mycoplasmas in the pools of the DS and SP4 medium was confirmed by the culture in SP4 agar plates. The plates were grown at $37{ }^{\circ} \mathrm{C}$ in $5 \% \mathrm{CO}_{2}$ and examined daily under a light microscope. No colonies were observed after 15 days in incubation. Mycoplasma bovis was further discarded in the pool of DS by polymerase chain reaction (PCR) from DNA extracted from $200 \mu \mathrm{L}$ of the culture [31,32].

Three replicates of this experiment were performed on different days. 


\subsection{M. bovis Viability}

Viable CFU/mL were determined at h0 and h15 in every condition contaminated with M. bovis (Table 1, $n=9$ ), as previously described [28], but diluted in the modified SP4 broth. Counts were conducted on the SP4 agar, after incubation at $37{ }^{\circ} \mathrm{C}$ for 48 hours and in $5 \% \mathrm{CO}_{2}$. For each replicate, counts were conducted in duplicate, with four dilutions for each contaminated condition, and at both times. Only counts with at least one visible mycoplasma were considered for statistical analysis.

\subsection{LAB Viability}

Viable LAB CFU/mL were determined in conditions 1 to 7 (Table 1) using a serial dilution method, as previously described [33]. In our study, dilutions were carried out in modified SP4 broth, and counts were conducted on MRS agar plates (MRS, Agar, Scharlau) after incubation at $37^{\circ} \mathrm{C}$ for $24 \mathrm{~h}$. For each replicate, counts were conducted on one dilution for each condition and time.

\subsection{Statistical Analysis}

Counts of $M$. bovis and LAB were transformed as $\log (1+C)$, where $C$ was the count obtained $(\mathrm{CFU} / \mathrm{mL})$ for each analytical condition and organism. Statistical analysis was performed using a general linear procedure implemented in the program Statistical Analysis System Institute (SAS) [34], following the model:

$$
Y_{i j k}=\mu+S_{i}+C_{j}+T_{k}+C T_{j k}+e_{i j k}
$$

where $Y_{\mathrm{ijk}}=\mathrm{pH}$ and $\log \mathrm{CFU} / \mathrm{ml}$ of $M$. bovis and LAB (dependent variables); $\mu=\mathrm{mean} ; S_{\mathrm{i}}=$ sample effect; $C_{j}=$ effect of analytical conditions; $T_{k}=$ effect of time; $\mathrm{CT}_{\mathrm{jk}}=$ effect of the interaction between the analytical condition and time; and $\mathrm{e}_{\mathrm{ijk}}=$ residual effect.

\section{Results}

In the proposed model, the condition itself, the time, and the interaction between the condition and the time had a significant effect on the $\mathrm{pH}$ and $\log \mathrm{CFU} / \mathrm{mL}$ of $M$. bovis and LAB. Table 2 shows the effect of each condition on $M$. bovis viability, regardless of the time, while Table 3 shows the effect of the time on the $\mathrm{pH}$ and the M. bovis and LAB viability in each condition separately. The addition of both concentrations of the probiotic and both antimicrobials to DS had a detrimental effect on the mycoplasma viability, since its concentration was lower $(p<0.05)$ than in untreated DS (Table 2, conditions 1,4 , 5,8 , and 9). However, the addition of the probiotic at a higher concentration (condition 5) had a greater impact $(p<0.05)$ on the pathogen viability than the addition of a less concentrated probiotic (condition 4) and was equivalent to the addition of enrofloxacin and doxycycline (conditions 8, 9).

Table 2. Least squares means of the Mycoplasma bovis log colony-forming units (CFU)/mL, according to the studied analytical conditions. Conditions not contaminated with mycoplasmas are not included.

\begin{tabular}{ccc}
\hline Condition & Description & Log CFU/mL of M. bovis ${ }^{1}$ \\
\hline 1 & DS + M. bovis & $6.71^{\mathrm{a}}$ \\
4 & DS + M. bovis + L1 & $4.55^{\mathrm{b}}$ \\
5 & DS + M. bovis + L2 & $3.93^{\mathrm{c}}$ \\
6 & SP4 + M. bovis + L1 & $7.73^{\mathrm{d}}$ \\
7 & SP4 + M. bovis + L2 & $7.7^{\mathrm{d}}$ \\
8 & DS + M. bovis + Enro & $4.09^{\mathrm{b}, \mathrm{c}}$ \\
9 & DS + M. bovis + Doxy & $3.72^{\mathrm{c}}$ \\
10 & SP4+ M. bovis + Enro & $3.43^{\mathrm{c}}$ \\
11 & SP4+ M. bovis + Doxy & $3.34^{\mathrm{c}}$ \\
\hline
\end{tabular}

Comparison of the means of $M$. bovis in all conditions, regardless of time. ${ }^{\mathrm{a}, \mathrm{b}, \mathrm{c}, \mathrm{d}}$ : Means with different superscripts between conditions differ significantly $(p<0.05) .{ }^{1}$ Standard error of the mean (SEM): 0.23. DS: Diluted semen. SP4: Specific medium for Mycoplasma spp. isolation (conditions without DS). L1: Lactobacillus spp. less concentrated $\left(3.24 \times 10^{6} \mathrm{CFU} / \mathrm{mL}\right)$. L2: Lactobacillus spp. more concentrated $\left(3.24 \times 10^{8} \mathrm{CFU} / \mathrm{mL}\right)$. Enro: Enrofloxacin. Doxy: Doxycycline. 
Table 3. Least squares means of the $\mathrm{pH}$ and $\log$ colony-forming units (CFU)/mL of Mycoplasma bovis and lactic acid bacteria, according to the analytical conditions studied by time.

\begin{tabular}{|c|c|c|c|c|c|}
\hline Condition & Description & Hour (h) & $\mathrm{pH}^{1}$ & $\begin{array}{l}\log C F U / \mathrm{mL} \\
\text { of } M . \text { bovis }^{2}\end{array}$ & $\begin{array}{c}\log \mathrm{CFU} / \mathrm{mL} \\
\text { of } \mathrm{LAB}^{3}\end{array}$ \\
\hline \multirow[t]{2}{*}{1} & $\mathrm{DS}+$ M. bovis & 0 & $6.93^{a}$ & $7.53^{a}$ & $0^{\mathrm{a}}$ \\
\hline & & 15 & $6.74^{\mathrm{a}}$ & $5.89^{b}$ & $3.82^{\mathrm{a}}$ \\
\hline \multirow[t]{2}{*}{2} & $\mathrm{DS}+\mathrm{L} 1$ & 0 & $6.93^{a}$ & - & $3.82^{\mathrm{a}}$ \\
\hline & & 15 & $6.73^{a}$ & - & $4.03^{\mathrm{a}}$ \\
\hline \multirow[t]{2}{*}{3} & $\mathrm{DS}+\mathrm{L} 2$ & 0 & $6.93^{a}$ & - & $3.20^{\mathrm{a}}$ \\
\hline & & 15 & $6.75^{a}$ & - & $3.91^{\mathrm{a}}$ \\
\hline \multirow[t]{2}{*}{4} & $\begin{array}{c}\mathrm{DS}+\text { M. bovis }+ \\
\mathrm{L} 1\end{array}$ & 0 & $6.93^{a}$ & $7.55^{a}$ & $2.73^{a}$ \\
\hline & & 15 & $6.74^{\mathrm{a}}$ & $1.55^{b}$ & $1.97^{\mathrm{a}}$ \\
\hline \multirow[t]{2}{*}{5} & $\begin{array}{c}\mathrm{DS}+\text { M. bovis }+ \\
\text { L2 }\end{array}$ & 0 & $6.93^{a}$ & $7.08^{a}$ & $4.23^{a}$ \\
\hline & & 15 & $6.50^{b}$ & $0.78^{b}$ & $13.62^{b}$ \\
\hline \multirow[t]{2}{*}{6} & $\mathrm{SP} 4+$ M. bovis + & 0 & $7.68^{a}$ & $7.50^{\mathrm{a}}$ & $4.38^{\mathrm{a}}$ \\
\hline & & 15 & $7.32^{b}$ & $7.95^{\mathrm{a}}$ & $2.06^{\mathrm{a}}$ \\
\hline \multirow[t]{2}{*}{7} & $\begin{array}{c}\mathrm{SP} 4+\text { M. bovis } \\
+\mathrm{L} 2\end{array}$ & 0 & $7.68^{a}$ & $7.22^{a}$ & $3.01^{\mathrm{a}}$ \\
\hline & & 15 & $7.21^{\mathrm{b}}$ & $8.19^{b}$ & $3.23^{\mathrm{a}}$ \\
\hline \multirow[t]{2}{*}{8} & $\begin{array}{c}\mathrm{DS}+\underset{\text { Enro }}{\text { M. bovis }}+ \\
\text { E }\end{array}$ & 0 & $6.93^{a}$ & $7.59^{a}$ & - \\
\hline & & 15 & $6.74^{\mathrm{a}}$ & $0.60^{b}$ & - \\
\hline \multirow[t]{2}{*}{9} & $\begin{array}{c}\text { DS }+ \text { M. bovis }+ \\
\text { Doxy }\end{array}$ & 0 & $6.93^{a}$ & $7.45^{\mathrm{a}}$ & - \\
\hline & & 15 & $6.74^{a}$ & $0^{b}$ & - \\
\hline \multirow[t]{2}{*}{10} & $\begin{array}{c}\mathrm{SP} 4+\text { M. bovis }+ \\
\text { Enro }\end{array}$ & 0 & $7.68^{a}$ & $7.11^{\mathrm{a}}$ & - \\
\hline & & 15 & $7.58^{a}$ & $0^{b}$ & - \\
\hline \multirow[t]{2}{*}{11} & $\begin{array}{c}\mathrm{SP} 4+\text { M. bovis }+ \\
\text { Doxy }\end{array}$ & 0 & $7.68^{a}$ & $6.93^{a}$ & - \\
\hline & & 15 & $7.68^{a}$ & $0^{\mathrm{b}}$ & - \\
\hline
\end{tabular}

${ }^{a}, b$ : Means with different superscripts between the times in all conditions differ significantly $(p<0.05) .{ }^{1}$ Standard error of the mean (SEM): $0.08 ;{ }^{2}$ SEM: $0.31 ;{ }^{3}$ SEM: 1.63 . DS: Diluted semen. SP4: Specific medium for Mycoplasma spp. isolation (conditions without DS). L1: Lactobacillus spp. less concentrated $\left(3.24 \times 10^{6} \mathrm{CFU} / \mathrm{mL}\right)$. L2: Lactobacillus spp. more concentrated $\left(3.24 \times 10^{8} \mathrm{CFU} / \mathrm{mL}\right)$. LAB: Lactic acid bacteria. Enro: Enrofloxacin. Doxy: Doxycycline. The $\mathrm{pH}$ values of the pools of DS and SP4 were considered as the initial $\mathrm{pH}(\mathrm{h} 0)$ of the conditions prepared in DS and SP4, respectively. The $\mathrm{pH}$ was measured in every condition separately at h15.

Considering the $\log \mathrm{CFU} / \mathrm{ml}$ of $M$. bovis and $\mathrm{LAB}$ variation over time (Table 3), a significant LAB growth was recorded in DS when adding L2 (condition 5), while a harmful effect on M. bovis viability was observed, since $\log \mathrm{CFU} / \mathrm{mL}$ decreased from 7.08 to $0.78(p<0.05)$. Besides, this effect on mycoplasma viability coincided with a decrease of the $\mathrm{pH}$ from 6.93 to $6.5(p<0.05)$. However, when adding the less concentrated probiotic, the pathogen survival was negatively affected, although no significant LAB growth was observed, and the $\mathrm{pH}$ remained constant (condition 4).

Both L1 and L2 remained viable in DS (conditions 2 and 3), although there was no significant LAB growth, and the $\mathrm{pH}$ remained constant. On the other hand, neither L1 nor L2 grew significantly in the contaminated SP4 (conditions 6 and 7), while the $\mathrm{pH}$ decreased $(p<0.05)$ from 7.6 to 6.73 when L1 was added, and from 7.6 to 7.21 when L2 was added. Furthermore, the viability of M. bovis was not affected, and its concentration increased $(p<0.05)$ in the L2 condition.

The viability of $M$. bovis was negatively affected $(p<0.05)$ over time in the untreated DS, since its concentration decreased from 7.53 to $5.89(p<0.05)$, while no significant variation was registered in the $\mathrm{pH}$, which was 6.74 after 15 hours of incubation (Table 3, condition 4). However, this detrimental effect on the pathogen viability was lower $(p<0.05)$ than that observed after the addition of the probiotic 
and antimicrobials (Table 2, conditions 1, 4, 5, 8, and 9). Furthermore, the counts of LAB were made in this condition (Table 3, condition 1), even though it had not been supplemented with the probiotic.

Concerning the antimicrobial conditions, the viability of the pathogen was negatively affected $(p<0.05)$ in DS and SP4, while the $\mathrm{pH}$ remained constant in all of them (Table 3, conditions 8, 9, 10, and 11).

The MIC value of PG45 for enrofloxacin was within the range of previously published studies applying microbroth dilution tests $[30,35]$. No published values are available for doxycycline.

\section{Discussion}

Our results show the in vitro susceptibility of $M$. bovis in DS after the addition of Lactobacillus spp. at a concentration of $3.24 \times 10^{6} \mathrm{CFU} / \mathrm{mL}$ or $3.24 \times 10^{8} \mathrm{CFU} / \mathrm{mL}$ and after the addition of $0.125 \mu \mathrm{g} / \mathrm{mL}$ enrofloxacin or $0.0625 \mu \mathrm{g} / \mathrm{mL}$ of doxycycline. While the Tris-citrate-fructose medium negatively affected the viability of M. bovis, this effect was lower than that observed after the addition of the probiotic and antimicrobials.

Several studies have demonstrated the inhibitory role of Lactobacillus spp. against human pathogenic bacteria, and they are mainly used for the treatment of vaginal dysbiosis [21,22]. Lacking a cell wall, mycoplasmas are very sensitive to $\mathrm{pH}$ variations [19], and so we thought that the addition of Lactobacillus spp.-based probiotics could affect the viability of $M$. bovis in DS due to the $\mathrm{pH}$ decrease after LAB proliferation. Indeed, this phenomenon was observed after the addition of the probiotic at a concentration higher than $10^{8} \mathrm{CFU} / \mathrm{mL}$. However, after adding the probiotic at a lower concentration, the viability of $M$. bovis was negatively affected, but no significant LAB growth nor $\mathrm{pH}$ decrease was observed. Nevertheless, the LAB counts were evidenced, so the competition for resources or the production of substances, such as hydrogen peroxide [21,22], could have affected the viability of the pathogen.

Interestingly, the viability of M. bovis in untreated DS was seriously affected after $15 \mathrm{~h}$ in incubation. This is consistent with previous observations in goat DS contaminated with mycoplasmas [20]. These authors demonstrated that the acidic $\mathrm{pH}$ of goat ejaculate $(\mathrm{pH} \geq 7)$ after dilution in the semen extender $(\mathrm{pH} \leq 6)$ caused a detrimental effect on $M$. agalactiae and M. mycoides susbs capri. Furthermore, the glycolytic activity of sperm in the semen extender contributes to the acidification of the medium, which may negatively affect the viability of mycoplasmas present in DS [20,36]. On the other hand, we confirmed that Lactobacillus spp. strains remained stable and viable in DS, which could be due to the presence of nutrients in the semen extender or even synergies occurring with the saprophytic semen flora. In this sense, previous authors have described the presence of LAB in bovine semen [23]. This could explain why counts of LAB were made in the contaminated DS, without the probiotic addition. Indeed, the natural presence of LAB in bovine semen could lead to a detrimental effect on $M$. bovis viability. However, since the ejaculate is diluted for the preparation of the seminal dose, the possible effect of LAB on the pathogen viability could be reduced. The addition of LAB in DS could compensate for the effect of the dilution.

The addition of the probiotic in SP4 did not negatively affect the viability of M. bovis. Indeed, LAB remained stable, and the concentration of $M$. bovis was significantly increased in condition 7, with L2. In this case, the significant decrease of $\mathrm{pH}$ in SP4 after the addition of M. bovis and the probiotic may be due to the metabolic activity of the viable bacteria present in the medium.

On the other hand, the addition of the antimicrobials, enrofloxacin $(0.125 \mu \mathrm{g} / \mathrm{mL})$ or doxycycline $(0.0625 \mu \mathrm{g} / \mathrm{mL})$, may be an effective measure to reduce the presence of $M$. bovis in DS. Some authors have reported a reduced efficacy of fluoroquinolones and doxycycline under low $\mathrm{pH}$ conditions, so the acidic $\mathrm{pH}$ of DS (6.93) could have affected their antimicrobial activity [37,38]. Nevertheless, the conditions prepared in SP4 ( $\mathrm{pH} 7.68)$ and DS ( $\mathrm{pH}$ 6.93) were equivalent, and the viability of the pathogen was negatively affected in all of them (Table 2, conditions $8,9,10$, and 11).

To the authors' knowledge, this is the first study that evaluates the effect of the addition of enrofloxacin, doxycycline, or the Lactobacillus spp.-based probiotic on M. bovis viability in bovine DS. 
Our results are promising in the field of bovine mycoplasmosis, as they may support new strategies for reducing the risk of $M$. bovis transmission through AI.

Despite the promising results, this study has several limitations. (1) Only the reference strain PG45 was considered, since this is a preliminary study. Further analyses should consider the effect of the studied conditions on M. bovis field isolates. (2) The effects on the sperm quality (viability, motility, and morphology) of the addition of the antimicrobials and the probiotic were not evaluated. Further investigations should be conducted to examine the effects, if any, of those compounds on bull sperm quality. Those studies should consider not only the concentrations employed here, but also concentrations below and above, to obtain the lower effect on sperm quality and the higher effect on M. bovis viability. Nevertheless, the main objective of this study was to evaluate the effect of the addition of those compounds on M. bovis viability. Hence, the authors believe that the results reported in the present essay are significant and worthy of consideration. Further studies should be conducted to fill the aforementioned gaps.

\section{Conclusions}

In the present study, we report the in vitro susceptibility of M. bovis (PG45, NCTC 10131) to the addition of Lactobacillus spp. at a concentration of $3.24 \times 10^{6} \mathrm{CFU} / \mathrm{mL}$ or $3.24 \times 10^{8} \mathrm{CFU} / \mathrm{mL}$ and to the addition of $0.125 \mu \mathrm{g} / \mathrm{mL}$ enrofloxacin or $0.0625 \mu \mathrm{g} / \mathrm{mL}$ of doxycycline in DS. The semen extender, Tris-citrate-fructose, also negatively affected the viability of the pathogen, although to a lesser extent than the addition of the probiotic and antimicrobials. Our results are promising in relation to the control of bovine mycoplasmosis, as they may support new strategies for reducing the risk of M. bovis transmission through AI.

Author Contributions: Conceptualization, Á.G.-M., E.B., J.G. (Jesús Gomis), E.G.-R. and C.D.l.F.; Data curation, A.G.-G. and Á.G.-M.; Formal analysis, A.G.-G., Á.G.-M., J.G. (Jesús Gomis) and C.D.l.F.; Funding acquisition, C.D.l.F.; Investigation, A.G.-G., Á.G.-M., J.G. (Joaquín Gadea) and C.D.1.F.; Methodology, A.G.-G., Á.G.-M., E.B., J.G. (Jesús Gomis), A.S., J.G. (Joaquín Gadea), L.A.V. and E.G.-R.; Project administration, C.D.1.F.; Resources, A.G.-G., Á.G.-M., J.G. (Jesús Gomis), J.G. (Joaquín Gadea), L.A.V. and C.D.l.F.; Software, A.G.-G. and A.S.; Supervision, Á.G.-M., A.S. and C.D.l.F.; Validation, A.G.-G., Á.G.-M., E.B., J.G. (Jesús Gomis), A.S., J.G. (Joaquín Gadea), L.A.V. and C.D.1.F.; Visualization, A.G.-G., Á.G.-M., A.S. and C.D.1.F.; Writing—original draft, A.G.-G., Á.G.-M. and C.D.I.F.; Writing-review \& editing, A.G.-G., Á.G.-M., E.B., J.G. (Jesús Gomis), A.S., J.G. (Joaquín Gadea), L.A.V., E.G.-R. and C.D.I.F.. All authors have read and agreed to the published version of the manuscript.

Funding: This work was supported by the Spanish Ministry of Economy and Competitiveness (Spanish Government) and co-financed by FEDER funds, project AGL2016-76568-R. Ana García-Galán is a beneficiary of a research fellowship (State Subprogram Training of the State Program for the Promotion of Talent and its Employability, BES-2017-080186).

Conflicts of Interest: The authors declare no conflict of interest. The funders had no role in the design of the study; in the collection, analyses, or interpretation of data; in the writing of the manuscript, or in the decision to publish the results

\section{References}

1. Nicholas, R.A.J.; Ayling, R.D. Mycoplasma bovis: Disease, diagnosis, and control. Res. Vet. Sci. 2003, 74, 105-112. [CrossRef]

2. Maunsell, F.P.; Brown, M.B.; Ivey, J.; Woolard, M.; Love, W.; Simecka, J.W. Oral inoculation of young dairy calves with Mycoplasma bovis results in colonization of tonsils, development of otitis media and local immunity. PLoS ONE 2012, 7, e44523. [CrossRef] [PubMed]

3. Kreusel, S.; Bocklisch, H.; Pfützner, H.; Brys, A.; Leirer, R.; Ziegenhals, U. Experimental infections of bulls with Mycoplasma (M.) bovis and M. bovigenitalium. Arch. Exp. Veterinarmed. 1989, 43, 705-712. [PubMed]

4. Ruhnke, H.L. Mycoplasmas associated with bovine genital tract infections. In Mycoplasmosis in Animals, 1st ed.; Whitford, H.W., Rosenbusch, R.F., Lauerman, L.H., Eds.; Iowa State University Press: Ames, IA, USA, 1994; pp. 56-61. 
5. Haapala, V.; Pohjanvirta, T.; Vähänikkila, N.; Halkilahti, J.; Simonen, H.; Pelkonen, S.; Soveri, T.; Simojoki, H.; Autio, T. Semen as a source of Mycoplasma bovis mastitis in dairy herds. Vet. Microbiol. 2018, 216, 60-66. [CrossRef] [PubMed]

6. Hirth, R.S.; Plastridge, W.N.; Tourtellotte, M.E. Survival of a mycoplasma in frozen bovine semen. Am. J. Vet. Res. 1967, 28, 97-99.

7. Amram, E.; Freed, M.; Khateb, N.; Mikula, I.; Blum, S.; Spergser, J.; Sharir, B.; Ozeri, R.; Harrus, S.; Lynsnyansky, I. Multiple locus variable number tandem repeat analysis of Mycoplasma bovis isolated from local and imported cattle. Vet. J. 2013, 197, 286-290. [CrossRef]

8. Bielanski, A.; Devenish, J.; Phipps-Todd, B. Effect of Mycoplasma bovis and Mycoplasma bovigenitalium in semen on fertilization and association with in vitro produced morula and blastocyst stage embryos. Theriogenology 2000, 53, 1213-1223. [CrossRef]

9. Eaglesome, M.D.; García, M.M. The effect of Mycoplasma bovis on fertilization processes in vitro with bull spermatozoa and zona-free hamster oocytes. Vet. Microbiol. 1990, 21, 329-337. [CrossRef]

10. Guérin, B.; Thibier, M. Value of adding antibiotics to frozen bovine semen: The example of mycoplasmas and campylobacters. Contracept. Fertil. Sex. 1993, 21, 753-759.

11. Bielanski, A. Disinfection procedures for controlling microorganisms in the semen and embryos of humans and farms animals. Theriogenology 2007, 68, 1-22. [CrossRef]

12. Vickram, A.S.; Kuldeep, D.; Archana, K.; Parameswari, R.; Ramesh, P.M.; Hafiz, M.N.I.; Sridharan, T.B. Antimicrobial peptides in semen extenders: A valuable replacement option for antibiotics in cryopreservationA prospective Review. J. Exp. Biol. Agric. Sci. 2017, 5, 578-588.

13. Shin, S.J.; Lein, D.H.; Patten, V.H.; Ruhnke, H.L. A new antibiotic combination for frozen bovine semen. Control of mycoplasmas, ureaplasmas, Campylobacter fetus subsp. venerealis and Haemophilus somnus. Theriogenology 1988, 29, 577-591. [CrossRef]

14. Visser, I.J.R.; ter Laak, E.A.; Jansen, H.B. Failure of antibiotics gentamycin, tylosin, lincomycin and spectinomycin to eliminate Mycoplasma bovis in artificially infected frozen bovine semen. Theriogenology 1999, 51, 689-697. [CrossRef]

15. Barberio, A.; Flaminio, B.; De Vliegher, S.; Supré, K.; Kromker, V.; Garbarino, C.; Arrigoni, N.; Zanardi, G.; Bertocchi, L.; Gobbo, F.; et al. Short communication: In vitro antimicrobial susceptibility of Mycoplasma bovis isolates identified in milk from dairy cattle in Belgium, Germany, and Italy. J. Dairy Sci. 2016, 99, 6578-6584. [CrossRef] [PubMed]

16. Heuvelink, A.; Reugebrink, C.; Mars, J. Antimicrobial susceptibility of Mycoplasma bovis isolates from veal calves and dairy cattle in the Netherlands. Vet. Microbiol. 2016, 189, 1-7. [CrossRef] [PubMed]

17. Eaglesome, M.D.; García, M.M.; Stewart, R.B. Microbial agents associated with bovine genital tract infections and semen. Part II. Haemophilus sommus, Mycoplasma spp and Ureaplasma spp, Chlamydia; Pathogens and semen contaminats; Treatment of bull semen with antimicrobial agents. Vet. Bull. 1992, 62, 887-910.

18. Gago, L.A.; Thomas, O.; Yurewicz, E.; Joshi, N.; Paine, T.; Puscheck, E.E. The effects of doxycycline on semen parameters. Fertil. Steril. 2004, 82, S170. [CrossRef]

19. Howard, C.J.; Gourlay, R.N. Mycoplasmas of animals. Sci. Prog. 1978, 65, 313-329.

20. Gómez-Martín, A.; Uc, N.; Vieira, L.A.; Gadea, J.; Cadenas, J.; Sánchez, A.; De la Fe, C. Survival capacity of Mycoplasma agalactiae and Mycoplasma mycoides subsp capri in the diluted semen of goat bucks and their effects on sperm quality. Theriogenology 2015, 83, 911-919. [CrossRef]

21. Charteris, W.P.; Kelly, P.M.; Morell, L.; Collins, K.J. Antibacterial activity associated with Lactobacillus gasseri ATCC 9857 from the human female genitourinary tract. World J. Microb. Biot. 2004, 17, 615-625. [CrossRef]

22. Eschenbach, D.A.; Davick, P.R.; Williams, B.L.; Klebanoff, S.J.; Young-Smith, K.; Critchlow, C.M.; Holmes, K.K. Prevalence of hydrogen peroxide-producing Lactobacillus species in normal women and women with bacterial vaginosis. J. Clin. Microbiol. 1989, 27, 251-256. [CrossRef] [PubMed]

23. González-Marín, C.; Roy, R.; López-Fernández, C.; Diez, B.; Carabaño, M.J.; Fernández, J.L.; Kjelland, M.E.; Moreno, J.F.; Gosálvez, J. Bacteria in bovine semen can increase sperm DNA fragmentation rates: A kinetic experimental approach. Anim. Reprod. Sci. 2011, 123, 139-148. [CrossRef] [PubMed]

24. Hill, H.J.; Scott, F.S.; Homan, N.; Gassner, F.X. Electroejaculation in the bull. J. Am. Vet. Med. Assoc. 1956, 128, 375-380. [PubMed] 
25. Bergqvist, A.S.; Ballester, J.; Johannisson, A.; Lundeheim, N.; Rodríguez-Martínez, H. Heparin and dermatan sulphate induced capacitation of frozen-thawed bull spermatozoa measured by merocyanine-540. Zygote 2007, 15, 225-232. [CrossRef] [PubMed]

26. Gadea, J.; Gumbao, D.; Gómez-Giménez, B.; Gardon, J.C. Supplementation of the thawing medium with reduced glutathione improves function of frozen-thawed goat spermatozoa. Reprod. Biol. 2013, 13, $24-33$. [CrossRef] [PubMed]

27. Waites, K.B.; Bébéar, C.M.; Robertson, J.A.; Talkington, D.F.; Kenny, G.E. Cumitech 34: Laboratory Diagnosis of Mycoplasmal Infections; American Society for Microbiology: Washington, DC, USA, 2001.

28. Albers, C.A.; Fletcher, R.D. Simple method for quantification for viable mycoplasma. Appl. Environ. Microbiol. 1982, 43, 958-960. [CrossRef]

29. Gómez-Martín, A.; De la Fe, C.; Amores, J.; Sánchez, A.; Contreras, A.; Paterna, A.; Buendía, A.J.; Corrales, J.C. Anatomic location of Mycoplasma mycoides subsp capri and Mycoplasma agalactiae in naturally infected goat male auricular carriers. Vet. Microbiol. 2012, 157, 355-362. [CrossRef]

30. Hannan, P.C.T. Guidelines and recommendations for antimicrobial minimum inhibitory concentration (MIC) testing against veterinary mycoplasma species. Vet. Res. 2000, 31, 373-395. [CrossRef]

31. Foddai, A.; Idini, G.; Fusco, M.; Rosa, N.; de la Fe, C.; Zinellu, S.; Corona, L.; Tola, S. Rapid differential diagnosis of Mycoplasma agalactiae and Mycoplasma bovis based on a multiplex-PCR and a PCR-RFLP. Mol. Cell. Probes. 2015, 19, 207-212. [CrossRef]

32. Tola, S.; Angioi, A.; Rocchigiani, A.M.; Idini, G.; Manunta, D.; Galleri, G.; Leori, G. Detection of Mycoplasma agalactiae in sheep milk samples by polymerase chain reaction. Vet. Microbiol. 1997, 54, 17-22. [CrossRef]

33. Bokma, J.; Pardon, B.; Van Driessche, L.; Gille, L.; Deprez, P.; Haesebrouck, F.; Boyen, F. Optimizing identification of Mycoplasma bovis by MALDI-TOF MS. Res. Vet. Sci. 2019, 125, 185-188. [CrossRef]

34. Statistical Analysis System (SAS); Institute Inc.: Cary, NC, USA, 2002.

35. Sulyok, M.; Kreizinger, Z.; Fekete, L.; Hrivnak, V.; Magyar, T.; Janosi, S.; Schweitzer, N.; Turcsányi, I.; Makrai, L.; Erdélyi, K.; et al. Antibiotic susceptibility profiles of Mycoplasma bovis strains isolated from cattle in Hungary, Central Europe. BMC Vet. Res. 2014, 10, 256. [CrossRef] [PubMed]

36. Díaz-García, F.J.; Herrera-Mendoza, A.P.; Giono-Cerezo, S.; Guerra-Infante, F.M. Mycoplasma hominis attaches to and locates intracellularly in human spermatozoa. Hum. Reprod. 2006, 21, 1591-1598. [CrossRef] [PubMed]

37. Smith, C.B.; Evavold, C.; Kersh, G.J. The effect of $\mathrm{pH}$ on antibiotic efficacy against Coxiella burnetii in axenic media. Sci. Rep. 2019, 9, 18132. [CrossRef] [PubMed]

38. Yang, L.; Wangc, K.; Li, H.; Densted, J.D.; Cadieux, P.A. The influence of urinary pH on antibiotic efficacy against bacterial uropathogens. Urology 2014, 84, 731. [CrossRef] [PubMed] 